\title{
Geometallurgical Studies on Gold Ore for Enhanced Comminution and Leaching*
}

\author{
${ }^{1}$ G. Ofori-Sarpong, ${ }^{2} \mathrm{~T}$. Okwaisie, ${ }^{1}$ R. K. Amankwah \\ ${ }^{1}$ University of Mines and Technology, Tarkwa, Ghana \\ ${ }^{2}$ Gold Fields Ghana Ltd, Damang Mine, Ghana
}

Ofori-Sarpong, G., Okwaisie, T. and Amankwah, R.K., (2019), "Geometallurgical Analysis of Ore for Enhanced Comminution and Leaching”, Ghana Mining Journal, Vol. 19, No. 1, pp. 59 - 65.

\begin{abstract}
Many gold processing plants are experiencing challenges as mining pits are becoming deeper, rocks are getting harder and more complex polymetallic and refractory ores are being encountered. The variations in the characteristics of ores lead to deviations from the established parameters, and these affect gold extraction efficiency. This paper presents a study where geological characteristics of the ore types from some mining pits were used to ascertain the influence of ore blends on improving the performances of comminution and leaching circuits. To achieve this, mineralogical, comminution, gravity recoverable gold and leaching investigations were conducted on fresh and weathered ore samples and their blends. Mineralogical study showed that the main rock types associated with the mine pits were dolerite, phyllites, conglomerates and sandstone. The dominant minerals were quartz, plagioclase, with traces of pyrites. The Crushability Work Indices of the rocks were between 30 and $37 \mathrm{KWh} / \mathrm{t}$, which are generally higher than the maximum design value of $31.9 \mathrm{kWh} / \mathrm{t}$, and this situation will pose throughput challenges in that section. The Bond Ball Mill Work Indices of the blends tested were between $16.4 \mathrm{kWh} / \mathrm{t}$ and $9.6 \mathrm{kWh} / \mathrm{t}$ and a blend ratio of $85 \%$ fresh and $15 \%$ weathered was found to have a Bond Ball Work Index almost equal to the design value of $14 \mathrm{kWh} / \mathrm{t}$. With gold assays of $2.5 \mathrm{~g} / \mathrm{t}$ for dolerite, $2.1 \mathrm{~g} / \mathrm{t}$ for phyllite, $3.7 \mathrm{~g} / \mathrm{t}$ for sandstone and $3.4 \mathrm{~g} / \mathrm{t}$ for conglomerate, the gravity recoverable gold was in the order of sandstone $36 \%>$ phyllite $(31.5 \%)>$ dolerite $(29.5 \%)>$ conglomerate $(18 \%)$. The overall gold recoveries were in the sequence of conglomerate $(95 \%)$, sandstone (94\%), phyllite $(92 \%)$ and dolerite $(87 \%)$. This information could be utilised in developing a proactive plant operations strategies for an operating plant in order to ultimately manage the plant and enhance achievement of set targets.
\end{abstract}

Keywords: Geometallurgy, Ore Blends, Characterisation, Communition Circuit Performance, Gold Recovery

\section{Introduction}

The heterogeneity associated with gold ores due to variations in mineralogy, grade, rock strength and gravity recoverable gold creates challenges in plant design and operations (Kesse, 1985; Hammond and Tabata, 1997). To put in place a proactive plant operations strategy, it is necessary to develop a geometallurgical map where the geological information is linked to the metal recovery characteristics. Geometallurgy integrates geological, mining and metallurgical information of an orebody, among others, to minimise technical and operational risks and to ensure effective utilisation of the existing ore resources for a more resilient operations (Dobby et al., 2004; Lamberg, 2011; David, 2014). Geometallurgical mapping generates site-specific techniques that depend on the mineralogy, chemical and metallurgical parameters of the ore (Jankovic and Valery, 2002; Adams, 2005; GEOMET, 2013) to generate a spatial model for production planning and management.

As mining progresses and pits become deeper, the continuous exploitation of gold ores may lead to changes in the established parameters for a particular processing plant due to variations in the characteristics of the ore which affect gold extraction efficiency (Jankovic and Valery, 2002; Zhou et al., 2004; Angove, 2005; Alruiz et al., 2009). Thus, geometallurgical mapping should be on-going as mining progresses because, for a given quantity of ore, there will generally be a decrease in the percentage of free-milling components and increased levels of complex polymetallic and refractory components. Also, as a given ore becomes more competent, its ability to undergo fracture reduces due to the increased work index, leading to coarser product particle sizes according to Equation 1 (Wills and Napier-Munn, 2006). In Equation 1, W is the specific energy or work done, $\mathrm{Wi}$ is the work index, $\mathrm{P}_{80}$ is $80 \%$ passing the expected product size and $\mathrm{F}_{80}$ is $80 \%$ passing the expected feed size. With an increase in work index, and a constant installed power of the mill, one or more of the other parameters would have to change for the available energy to remain same.

$$
\mathrm{W}=10 \mathrm{Wi}\left[\frac{1}{\sqrt{P_{80}}}-\frac{1}{\sqrt{F_{80}}}\right]
$$

The characteristics (e.g. hardness, mineralogy and grade) of an ore to be processed cannot be overlooked in gold extraction as they play an important role in the process options and engineering considerations of the flowsheet design (Williams and Holtzhausen, 2001; Wharton, 2004; Angove, 2005; Chryssoulis and McMullen, 2005). To ensure consistency, some mining companies 
blend primary and weathered ores by drawing from run-of-mine pads where the ores are stored based on lithology as well as average grades. Blending can be optimised by using stochastic approaches (King, 2001; Kumral, 2003; Amir Abrishamifar, 2011). On a given mine, diminishing weathered oxide ore reserves call for increased proportion of primary harder ores in the feed blend for comminution, and this leads to fluctuations in particle size distribution of the mill product (Fuerstenau and Han, 2003; Wills and NapierMunn, 2006; Clermont and de Haas, 2008), thus influencing the performance of the mills and subsequent units adversely. Where feed size is not well controlled, stability problems with associated mill product are created. In solving this problem and optimising the throughput of processing mills, some modifications including changes to blasting practices, Run-of-Mine (ROM) stockpiling, secondary crushing circuit and selective prescreening of Semi-Autogenous Grinding (SAG) mill feed may be required (Dobby et al., 2004; Angove, 2005; Chryssoulis and McMullen, 2005; Clermont and de Haas, 2008).

Gold recovery from ores is generally very sensitive to grind size but due to the changes in blend ratios and ore hardness, particle size of mill products deviates from design values over time. Currently, most plants target $\mathrm{P}_{80}$ of $106 \mu \mathrm{m}$, but values between $125 \mu \mathrm{m}$ and $150 \mu \mathrm{m}$ are common, thereby causing leaching tanks to experience siltation due to coarse mill product (Konadu et al., 2014; Osei et al., 2016) with concomitant decrease in gold recovery levels. The changes in ore blend ratios can also result in decreased plant throughput, excessive wear of the steel balls and mill liners, and decrease in overall gold recovery (Marsden and House, 2006; Wills and Napier-Munn, 2006).

This paper presents a study aimed at getting indepth understanding of the feed characteristics including the ore mineralogy, optimum blending ratios, work indices, power draw and its implication on mill product particle size and throughput so as to optimise the performance of the comminution and leaching circuits of the selected Mine.

\section{Resources and Methods Used}

\subsection{Materials Used}

The ore types used for this study were taken from four active pits of a mine in Ghana. Within the ore types (fresh and weathered), the identifiable rock types were conglomerates, phylites, sandstone and dolerite. Fifty kilograms each of weathered and fresh ores of particle sizes in the range of $200 \mathrm{~mm}$ to $50 \mathrm{~mm}$ were collected and used for the study.
The ore samples were dried at $105{ }^{\circ} \mathrm{C}$ to constant weight. Various blends of samples were prepared at 95\%:5\%, 90\%:10\%, 85\%:15\%, 80\%:20\% ratios of fresh to weathered. Chemical grade sodium cyanide and calcium hydroxide used for the study were obtained from Alfa Aesar.

\subsection{Chemical and Mineralogical Analysis}

Samples of the various ore-types were crushed sequentially through jaw, cone and roll crushers. Sub-samples of size $-2 \mathrm{~mm}$ were milled to $75 \mu \mathrm{m}$ and the gold determined by conventional fire assaying.

Mineralogical investigations were done by megascopic analysis as well as thin and polish section microscopy using Leica DMC polarising microscope and Leitz optical microscope respectively.

\subsection{Bond Crushability Work Index}

The Crushability Work Index (CWI) of selected rock specimens of size passing $75 \mathrm{~mm}$ square grid and retained on $50 \mathrm{~mm}$ square was determined using Bond Crushability Index Machine. Pieces of rocks were placed on a pedestal and broken by a known load. The CWI from the average of five tests was determined using the formula in Equation 2 , where $(\mathrm{Eb} / \mathrm{d})$ is the impact crushing strength in Joules per mm of rock thickness, SG is the specific gravity of the rock, and the CWI is the crushing work index in $\mathrm{kWh} / \mathrm{t}$.

$$
\mathrm{CWI}=53.49\left(\frac{\mathrm{Eb} / \mathrm{d}}{\mathrm{SG}}\right)
$$

\subsection{Bond Ball Mill Work Index}

Samples from the fresh, weathered and the various blends were used for the Bond Ball Mill Work Index test using the standardised procedure detailed by F. C. Bond (Napier-Munn et al., 1996). The sample was stage-crushed to $100 \%$ passing 3.35 mm using lab-size jaw, cone and roll crushers. Samples were then split using the riffle sampler for the Bond work index test. A known volume of ore $(700 \mathrm{ml})$ was ground in Standard Bond Mill for a counted number of revolutions. The ground material was screened at a test aperture of $106 \mu \mathrm{m}$. Fresh feed was added to the $+106 \mu \mathrm{m}$ fraction to make up to the original test weight. The number of mill revolutions was adjusted at each cycle until a stable recirculating load of $250 \%$ was achieved. The work index is calculated using the formula in Equation 3, where $\mathrm{Wi}$ is Work index value expressed in $\mathrm{kWh} /$ tonne, $\mathrm{P}_{106}$ is Grindability test aperture $(\mu \mathrm{m}), \mathrm{Gbp}$ is mean of equilibrium grindability values $(\mathrm{g} / \mathrm{rev}), \mathrm{P}_{80}$ is $80 \%$ passing size 
of the equilibrium product $(\mu \mathrm{m})$ and $\mathrm{F}_{80}$ is $80 \%$ passing size of the feed $(\mu \mathrm{m})$.

$$
W_{i}=\frac{44.5}{P_{106}^{0.233} \times(G p b)^{0.82} \times\left(\frac{10}{\sqrt{P_{80}}}-\frac{10}{\sqrt{F_{80}}}\right)}
$$

\subsection{Gravity Gold Recovery and Cyanidation Studies}

The ores were crushed to $-2 \mathrm{~mm}$ and a milling curve developed to ascertain the time required to grind to $80 \%$ passing $106 \mu \mathrm{m}$. Sub-samples were taken for grade determination by conventional fireassaying. Five (5) kilograms of milled ore was subjected to gravity concentration in a 3-inch Knelson Concentrator operating at a fluidising pressure of 1 psi. The concentrate was assayed for gold by conventional fire assaying and the tailings samples were used for leaching by cyanidation.

Each $1 \mathrm{~kg}$ sample was mixed with water in 4-L standard leach bottle at $50 \%$ solids at a controlled $\mathrm{pH}$ of 10.5 and cyanide $(\mathrm{CN})$ concentration of $150 \mathrm{ppm}$. In the course of leaching, residual cyanide was analysed using 0.0096 molar solution of silver nitrate by titration, and the leaching solution was replenished with additional cyanide to the original concentration. The $\mathrm{pH}$ was also monitored using Beckman $\mathrm{pH}$ meter and the level was maintained at 10.5 using lime. After leaching for 24 hours, the contents in the 4-L bottles were filtered and the tailings washed with water to remove any residual dissolved gold before fire assaying. The filtrate was analysed for gold concentration using AA240 AF Varian Atomic Adsorption Spectrometer (AAS), while the residual cake was dried and assayed for gold using standard fire assay method.

\section{Results and Discussion}

\subsection{Chemical and Mineralogical Analysis}

\subsubsection{Chemical Analysis}

The grade of gold in the various rocks are presented in Table 1, with sandstone having the highest $(3.7 \mathrm{~g} / \mathrm{t})$ and phyllite, the lowest $(2.1 \mathrm{~g} / \mathrm{t})$.

\section{Table 1 Head Assays of the Gold Ores}

\begin{tabular}{|c|c|c|c|c|}
\hline $\begin{array}{c}\text { Sample/ } \\
\text { gold } \\
\text { grade, g/t }\end{array}$ & 2.7 & 2.1 & 3.7 & 3.4 \\
\cline { 2 - 5 } & Dolerite & Phyllite & Sandstone & Conglomerate \\
\hline
\end{tabular}

\subsubsection{Rock and Mineral Identification}

Mineralogical analysis was conducted to ascertain the lithological composition of the major rocks in the various pits. By megascopic analysis, the identifiable rock types were phyllite, dolerite, conglomerate and sandstone. Figs. 1 to 4 respectively show photomicrographs of phyllite, conglomerates, dolerite and sandstone. In each of the Figs. (a) represents the images obtained under plane polarised light and (b), crossed polarised light.
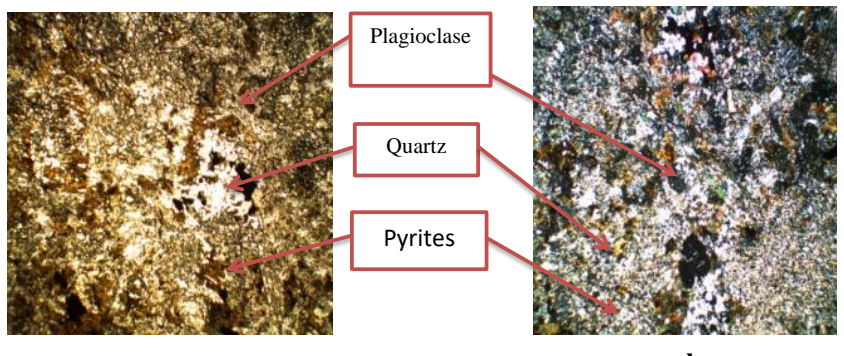

b

Fig. 1 Photomicrograph of Phyllite Samples in (a) Plane and (b) Cross Polarised Light

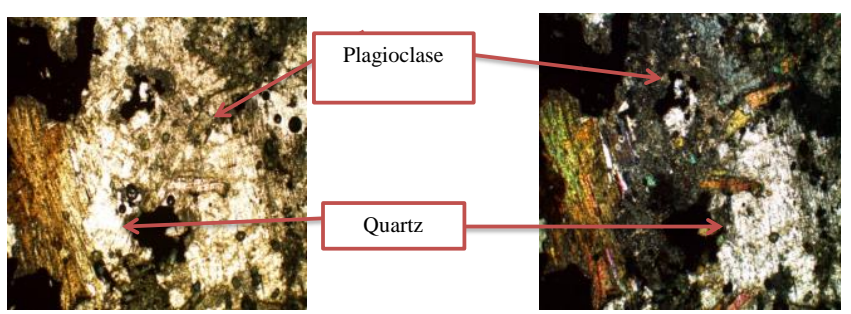

a

Fig. 2 Photomicrograph of Conglomerate Samples in (a) Plane and (b) Cross Polarised Light

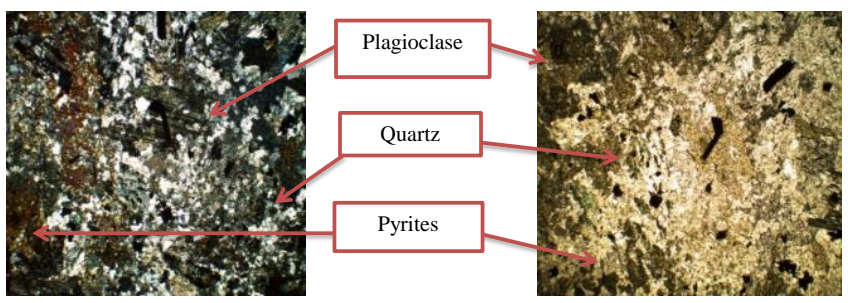
b

Fig. 3 Photomicrograph of Dolerite Samples in (a) Plane and (b) Cross Polarised Light

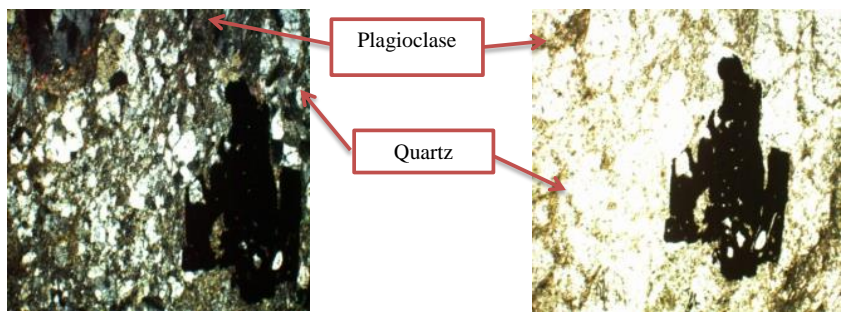

a

b

Fig. 4 Photomicrograph of Sandstone Samples in (a) Plane and (b) Cross Polarised Light 
The observation indicates that the four ore samples showed similar mineralogical compositions mainly quartz (which is very competent) and plagioclase. From the plane polarised view, it was observed that, there were some sulphide minerals in the phyllite and dolerite rocks. These may not necessarily contain gold. Of the sulphide minerals present, only pyrite occurred in significant concentrations in dolerite and phyllite.

\subsection{Crushability Work Index}

The Crushability Work Index (CWI) test was conducted on the fresh ore types from the pits, which were grouped into phyllite, dolerite, conglomerates and sandstones. Each rock type exhibited different resistance to crushing as presented in Fig. 5.

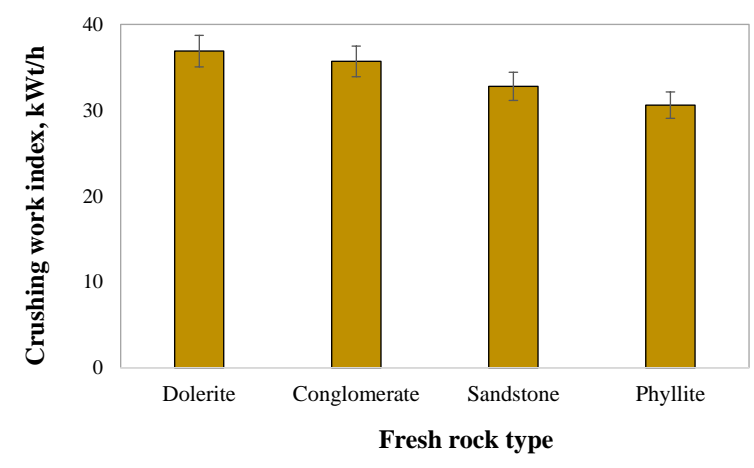

Fig. 5 The CWI of the Rock Types

The results in Fig. 5 show that dolerite has the highest Crushability Work Index (CWI) of 37 $\mathrm{KWh} / \mathrm{t}$ followed by conglomerate, sandstone and phyllite with values; $36.7 \mathrm{KWh} / \mathrm{t}, 32.8 \mathrm{KWh} / \mathrm{t}$ and $30.6 \mathrm{KWh} / \mathrm{t}$ respectively. This indicates that, the competency of the rock types decreases in the order of Dolerite $>$ Conglomerate $>$ Sandstone $>$ Phyllite. Dolerites are generally intrusive rocks from magma and this may account for its high crushing strength. The conglomerate is also made of quartz pebbles that are hard (Kesse, 1985). These values are significantly higher values compared with the design CWI of the plant under consideration which is an average of $25.9 \mathrm{KWh} / \mathrm{t}$ with the minimum being $19.8 \mathrm{KWh} / \mathrm{t}$ and the maximum, $31.9 \mathrm{KWh} / \mathrm{t}$. By implication, the four rock types, on the average, will pose a higher resistance to crushing than the ore type used in designing the plant, which may create a constraint in the tonnage crushed per unit time. In a situation where only hard rocks are available, the mine-to-mill concept may be adopted to reduce rock strength through intensive blasting (Eloranta, 1995). The weathered material could not be subjected to this test because they could not be cut to the appropriate size due to their softness.

\subsection{Bond Work Index}

To conduct the Bond Ball Mill Work Index tests, different blend ratios of fresh $(\mathrm{F})$ and weathered (Wd) materials (F100\%:Wd0\%, F95\%:Wd5\%, F90\%:Wd10, F85\%:Wd15\%, F80\%:Wd20\% and $100 \% \mathrm{~W})$ from the pits were used. More of the fresh material was used due to relative abundance. The various samples were prepared from a collection of fresh materials from the pit with lateritic or weathered material which was mined from a different pit, and a blend composition was prepared at various percentages from $100 \%$ fresh material down to $0 \%$ fresh material (100\% weathered). Each blend had similar amounts of the rock types, and the summarised results are presented in Table 2 and Fig. 6. The work indices were in the order of 16.4 $\mathrm{kWh} / \mathrm{t}$ for $100 \%$ fresh rock (F100\%:Wd0\%), 15.5 $\mathrm{kWh} / \mathrm{t}$ for $95 \%: 5 \%, 14.4 \mathrm{kWh} / \mathrm{t}$ for $90 \%: 10 \%, 13.9$ $\mathrm{kWh} / \mathrm{t}$ for $85 \%: 15 \%$ and $13.4 \mathrm{kWh} / \mathrm{t}$ for F80\%:Wd20\%. The $100 \%$ weathered ore gave the lowest value of $9.6 \mathrm{kWh} / \mathrm{t}$. The design work index is $14.0 \mathrm{kWh} / \mathrm{t}$, which is nearest to the value obtained for the blend of $85 \%$ fresh and $15 \%$ weathered. As presented in the comments in Table 2 , rocks with work indices between $7 \mathrm{kWh} / \mathrm{t}$ and 9 $\mathrm{kWh} / \mathrm{t}$ are regarded as soft, $9-14 \mathrm{kWh} / \mathrm{t}$ are medium and above $14 \mathrm{kWh} / \mathrm{t}$ are hard rocks (Napier-Munn et al., 1996; Wills and Napier-Munn, 2006)

Table 2 Summary Results of the Bond Work Index (BWI)

\begin{tabular}{|l|c|l|}
\hline Ore blend & $\begin{array}{l}\text { Bond work } \\
\text { index, kWh/t }\end{array}$ & Comments \\
\hline $100 \%$ fresh & 16.4 & Hard rock \\
\hline $\begin{array}{l}95 \% \text { fresh/5\% } \\
\text { weathered }\end{array}$ & 15.5 & Hard Rock \\
\hline $\begin{array}{l}90 \% \text { fresh/10\% } \\
\text { weathered }\end{array}$ & 14.4 & Hard rock \\
\hline $\begin{array}{l}85 \% \text { fresh/15\% } \\
\text { weathered }\end{array}$ & 13.9 & $\begin{array}{l}\text { Medium } \\
\text { strength }\end{array}$ \\
\hline $\begin{array}{l}80 \% \text { fresh/20\% } \\
\text { weathered }\end{array}$ & 13.4 & $\begin{array}{l}\text { Medium } \\
\text { strength }\end{array}$ \\
\hline $\begin{array}{l}100 \% \\
\text { weathered }\end{array}$ & 9.6 & $\begin{array}{l}\text { Medium } \\
\text { strength }\end{array}$ \\
\hline
\end{tabular}

From the above, the hardness levels were medium and hard indicating the level of competency associated with the blend types. Fig. 6 depicts the trend of the Bond Ball Mill Work indices which indicates that, the ore's competency increases with increase in the percentage of fresh material in the feed. 


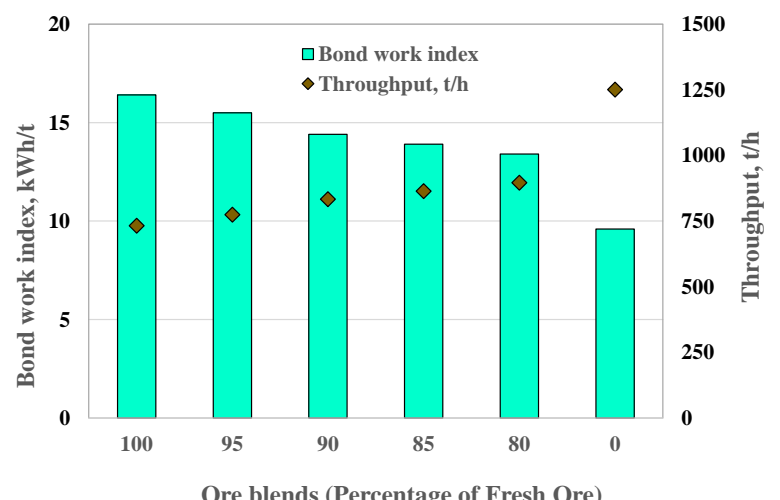

Fig. 6 Throughput and Bond Work Index of the Blends

The trend implies that the energy required to mill an amount of a given feed material varies with the ore type. Equation 4 shows the dependence of power $(\mathrm{P})$ on tonnage $(\mathrm{T})$ and work done $(\mathrm{W})$. Given a fixed tonnage, an increase in work index (Equation 1) will lead to an increase in power requirements. With a motor already in place with an installed power, an increase in work index will demand a cut-back on tonnage. As the work indices increase with an increase in the percentage of fresh material in the blend, it follows from Equation 4 that the power demand will increase correspondingly.

$$
P=T * W
$$

With an installed power of $12 \mathrm{MW}$, for example, it is necessary to predict the maximum tonnage for any given work index if the expected product size of $80 \%$ passing $106 \mu \mathrm{m}$ is to be achieved. Using the formula in Equation 4, it depicted in Fig. 6 that at Bond work index of $16.4 \mathrm{kWh} / \mathrm{t}$ (100\% fresh), the throughput was $732 \mathrm{t} / \mathrm{h}$. The throughput increased consistently as the work indices decreased with the blends, reaching $1250 \mathrm{t} / \mathrm{h}$ at Bond work index of $9.6 \mathrm{kWh} / \mathrm{t}$ (100\% weathered). At a design operating capacity of $860 \mathrm{t} / \mathrm{h}$, blending simulation has to be done to achieve the required tonnage without loss in grade and recovery (King, 2001; Kumral, 2003; Amir Abrishamifar, 2011). Based on the above, feeding $100 \%$ fresh material will reduce the throughput expectations of the processing plant and generate high mill weight and power. It will also generate low percentage of fines and therefore generate particle sizes which do not freely exit the mill, thereby causing the operating power to be higher than the design of $12 \mathrm{MW}$ (Wills and Napier-Munn, 2006). The 85\% Fresh ore with $15 \%$ weathered material attained a work index of $13.9 \mathrm{kWh} / \mathrm{t}$ and throughput of $863.3 \mathrm{t} / \mathrm{h}$. Since this work index was closest to the design value of $14.0 \mathrm{kWh} / \mathrm{t}$, the blend was selected for further gold extraction studies.

\subsection{Gravity Gold Recovery and Cyanidation Studies}

The blend that met the expectations of the grinding circuit was selected for Gravity Recoverable Gold (GRG) and cyanide amenability studies. The tailings from the GRG study were then leached with cyanide. Fig. 7 shows the GRG, gold recovered by cyanidation at $80 \%$ passing $106 \mu \mathrm{m}$ and the overall gold recovery.

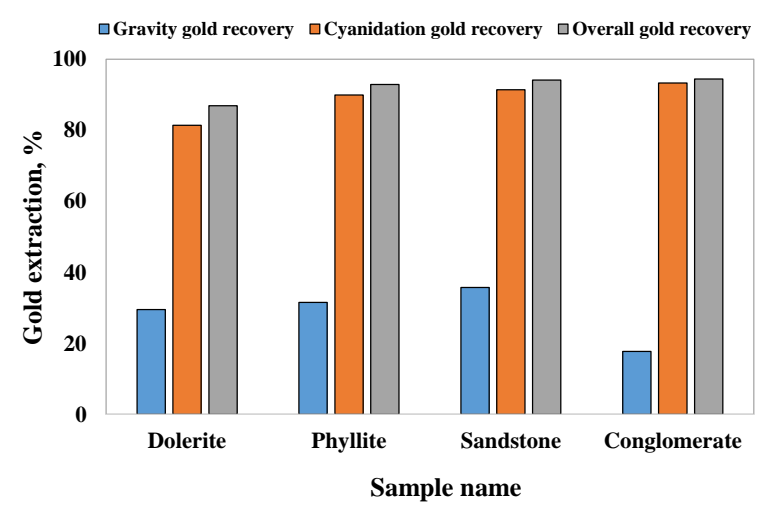

Fig. 7 Gold Recovery by Gravity and Cyanidation of the $85 \%$ fresh and $15 \%$ Weathered Blend

The results show that gravity recoverable gold was highest in the sandstone material at $36 \%$ followed by phyllite (31.5\%), dolerite (29.5\%) and conglomerate at $18 \%$. Thus, depending on the type of ore being fed to the plant, the GRG could be predicted. The variations in gravity gold recovery may be attributed to the amount of coarse gold in each ore-type.

When the plant is behind gold production target, behind schedule, and cannot wait for long leaching times, feeding more sandstone material can help recover much gold within a shorter time. Though the conglomerate had the lowest gravity recoverable gold, it achieved the highest cyanidation recovery of $93.3 \%$ and overall recovery of $95 \%$. The overall recovery trend for the rest was in the order of sandstone (94\%), phyllite $(92 \%)$ and dolerite $(87 \%)$. The dolerite had the lowest cyanidation recovery of $81 \%$. This could be attributed to the fact that dolerite is an intrusive rock and the hardest among the four, thus reducing lixiviant-gold particle interaction. In addition, it contained pyrites, which may not be amenable to direct cyanidation.

\section{Conclusions and Recommendations}

This work focussed on getting understanding of ore characteristics on metallurgical extraction of gold with respect to size reduction behaviour and 
recovery. Mineralogical study showed that the main rock types associated with the mine pits were dolerite, phyllites, conglomerates and sandstone. The dominant minerals were quartz, plagioclase, with traces of pyrites. The Crushability Work Index recorded higher indices $(37-30.6 \mathrm{KWh} / \mathrm{t})$ than the maximum design value of $31.9 \mathrm{kWh} / \mathrm{t}$, and this indicates that achieving the design tonnage could be a challenge in that section. The Bond Ball Mill Work Indices of the blends tested, were between $16.4 \mathrm{kWh} / \mathrm{t}$ and $9.6 \mathrm{kWh} / \mathrm{t}$. A blend ratio of $85 \%$ fresh and $15 \%$ weathered was found to have a Bond Ball Work Index almost equal to the design value of $14 \mathrm{kWh} / \mathrm{t}$. Further studies on this blend ratio showed gold grades of $2.5 \mathrm{~g} / \mathrm{t}$ for dolerite, 2.1 $\mathrm{g} / \mathrm{t}$ for phyllite, $3.7 \mathrm{~g} / \mathrm{t}$ for sandstone and $3.4 \mathrm{~g} / \mathrm{t}$ for conglomerate. Based on the relative abundance of these materials, and the grades, a blend that helps to achieve targeted ounces can always be determined. The gravity recoverable gold was in the order of sandstone $36 \%>$ phyllite $(31.5 \%)>$ dolerite $(29.5 \%)>$ conglomerate $(18 \%)$. Based on the cyanide amenability, the overall recoveries were in the sequence of conglomerate (95\%), sandstone $(94 \%)$, phyllite $(92 \%)$ and dolerite $(87 \%)$.

With this knowledge, depending on the type of ore being fed to the plant, the GRG can be predicted and specific actions can be taken to ensure that target ounces are achieved by going for more gravity gold when management cannot wait for long leaching times before shipment. By feeding more sandstone material, more gold can be recovered by gravity within a shorter time. In addition, the expected leaching recovery can be predicted and attained based on the mix of material that the plant is fed with. Depending on the relative abundance of these rocks, it may happen that getting specific ratios for blending may be challenging. In such situations, if the harder rocks are predominant, then the Mine-to-Mill concept may be adopted so that appropriate powder factors may be used to achieve reduced rock strength.

\section{References}

Adams, M. D. (2005), Advances in Gold Processing, Developments in Mineral Processing, Elsevier, 1077 pp.

Angove, J. (2005), "Metallurgical Testwork: Gold Processing Options, Physical Ore Properties and Cyanide Management", Advances in Gold Ore Processing, Elsevier, M. D. Adams (ed.), pp. 97 $-107$.

Alruiz, O. M., Morrell, S., Suazo, C. J. and Naranjo, A. (2009), "A Novel Approach to the Geometallurgical Modelling of the Collahuasi Grinding Circuit”. Minerals Engineering, Vol.
22 , pp. 1060-1067. DOI 10.1016/j.mineng. 2009.03.017.

Amir Abrishamifar, S., (2011), "Ore Extraction and Blending Optimisation Model in Poly-metallic Open Pit Mines by Chance Constrained OneSided Goal Programming", Journal of Industrial Engineering International, Vol. 1 No. 15, pp. $60-67$. ISSN: 1735-5702.

Chryssoulis, S. L., and McMullen, J. (2005), "Mineralogical Investigation of Gold Ores" Advances in Gold Ore Processing, Elsevier, M. D. Adams (ed.), pp. $21-71$.

Clermont, B. and de Haas, B. (2008), "Optimisation of Mill Performance by using Online Ball and Pulp Measurements", The Southern African Institute of Mining and Metallurgy, Vol. 10, pp. 133 - 140.

David, D. (2014), "Geometallurgical Guidelines for Miners, Geologists and Process Engineer Discovery to Design". In Mineral Resource and Ore Reserve Estimation Guide to Good Practice; Australasian Institute of Mining and Metallurgy, Melbourne, Australia, pp. 443-450.

Dobby, G., Bennett, C., Bulled, D. and Kosick, X. (2004). "Geometallurgical Modelling - The New Approach to Plant Design and Production Forecasting/Planning, and Mine/Mill Optimization". In Proceedings of 36th Annual Meeting of the Canadian Mineral Processors, Ottawa, Canada, Paper No.15.

Eloranta, J. W. (1995), "The Effect of Fragmentation on Downstream Processing Costs", In Proceedings of Explo95 Conference, Brisbane, Qld, Australia, Sept. 4-7, pp 25-28.

Fuerstenau, M. C. and Han, K. N. (2003), "Principles of Mineral Processing", Society of Mining, Metallurgy, and Exploration, Inc. (SME), Littleton, Colorado,, USA, 577 pp.

GEOMET (2013), The second AusIMM International Geometallurgy Conference (GeoMet), Brisbane, Australia, 354 pp.

Hammond, N. Q. and Tabata, H. (1997), "Characteristics of Ore Minerals Associated with Gold at the Prestea Mine, Ghana", Mineralogical Magazine, Vol. 61, pp. 879-894.

Jankovic, A., and Valery, W., (2002), "Mine to Mill Optimisation for Conventional Grinding Circuits - A Scoping Study" Journal of Mining and Metallurgy, Vol. 38, pp. 49-66.

Kesse, G. O. (1985), The Mineral and Rock Resources of Ghana, A. A. Balkema, Rotherdam, $610 \mathrm{pp}$.

King, R. P. (2001), Modeling and Simulation of Mineral Processing Systems, ButterworthHeinemann, A Division of Reed Educational and Professional Publishing Ltd, Woburn, Boston, USA, 403 pp.

Kumral, M. (2003), "Solution of Ore Blending Problem by Stochastic Approach", In Proceedings of the $10^{\text {th }}$ International Mining 
Congress and Exhibition of Turkey-IMCET, pp. 485 - 490, ISBN 975-395-605-3.

Konadu, K. T., Abaka-Wood, G. B. and OforiSarpong, G. (2014), "Gold Loses due to Silt Formation in Leaching Tanks", In Proceedings of the3rd UMaT Biennial International Mining and Mineral Conference, pp. 289-293.

Lamberg, P. (2011), "Particles - the Bridge Between Geology and Metallurgy", In Proceedings of the Conference in Mineral Engineering, Luleå, Sweden, pp. 1-16.

Marsden, J. O. and House, C. I. (2006), The Chemistry of Gold Extraction, Society of Mining, Metallurgy, and Exploration, Inc. (SME), Littleton, Colorado, USA, $651 \mathrm{pp}$.

Napier-Munn, P., Morrell S., Morrison R.D., Kojovic T. (1996). "Mineral Comminution Circuits: Their Operation and Optimization", $J K M R C$, Brisbane, 413 pp.

Osei, R., Abaka-Wood, G. B., Ofori-Sarpong, G. and Amankwah, R. K. (2016), "Siltation of Ore Particles in Leaching Tanks: Causative Factors and Mitigation Measures", Ghana Mining Journal, Vol. 16, No. 2, pp. 51 - 57.

Wharton, C. (2004), "The Use of Extractive Blending Optimisation for Improved Profitability", Orebody Modelling and Strategic Mine Planning, Perth, West Australia, pp. 6976.

Williams, N. R. and Holtzhausen, S. (2001), "The Impact of Ore Characterization and Blending on Metallurgical Plant Performance", Journal of The South African Institute of Mining and Metallurgy, pp. 437-446.

Wills, B. A. and Napier-Munn, T. (2006), Will's Mineral Processing Technology, Elsevier Science and Technology Books, $444 \mathrm{pp}$.

Zhou, J., Jago, B. and Martin, C. (2004), "Establishing the Process Mineralogy of Gold Ores", SGS Minerals Technical Bulletin, No. 2004-03, 16 pp.

\section{Authors}

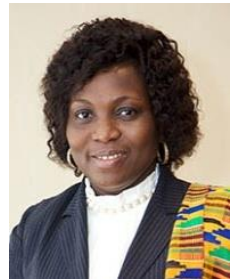

Grace Ofori-Sarpong is an Associate Professor of Minerals Engineering at the University of Mines and Technology, Tarkwa. She holds PhD in Energy and Mineral Engineering from Pennsylvania State University, MSc in Environmental Resources Management and BSc in Metallurgical Engineering, both from the Kwame Nkrumah University of Science and Technology, KNUST, Kumasi, Ghana. Her areas of research interest include microbial-mineral interaction, acid mine drainage issues, microwaves in extractive metallurgy, geometallurgy of gold and small-scale gold mining. She is a member of Society for Mining, Metallurgy and Exploration Engineers (SME), Society of Petroleum Engineers (SPE) and Women in Mining (WiM). She is also a Fellow of Ghana Academy of Arts and Sciences and West African Institute of Mining, Metallurgy and Petroleum (WAIMM).

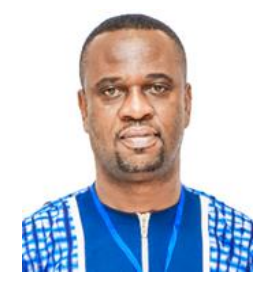

Timothy Okwaisie is a Metallurgist at the processing Dept of Goldfields at Damang. He holds Master of Science Degree in Mineral Engi-neering at University of Mines and Technology (UMaT), Tarkwa. He holds a Diploma in Mineral Technology from Kwame Nkrumah University of Mines and Technology, KNUST Kumasi, Ghana. He has Processing Supervisors and Metallurgical Superintendent certificates of competency from the inspectorate Division of Minerals Commission. He also has a certificate of competency for outstanding performance in the cyanide awareness operations and standard operating procedures of Abosso Goldfields Limited. His areas of research interest include geometallurgy of gold and small-scale gold mining. He is a member of the Ghana Institute of Engineering (GHIE).

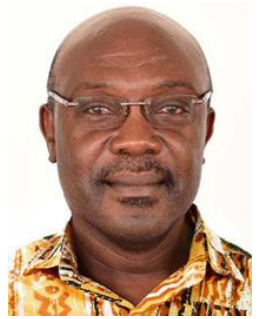

Richard K Amankwah is a Professor of Minerals Engineering at the University of Mines and Technology (UMaT), Tarkwa, Ghana. He holds a $\mathrm{PhD}$ degree in Mining Engineering from Queen's University, Canada, and MPhil and BSc in Metallurgical Engineering from the Kwame Nkrumah University of Science and Technology, KNUST, Kumasi, Ghana. His research interests include gold beneficiation, water quality management, microwave processing of minerals, small-scale mining, medical geology, microbial mineral recovery and environmental biotechnology. He is a Fellow of the West African Institute of Mining, Metallurgy and Petroleum (WAIMM), a member of the Ghana Institution of Engineers and the Society for Mining, Metallurgy and Exploration Engineers (SME). 